\title{
Potentials and Integrated Suitability Pre-assessment of Wastewater Treatment Plants as Local Energy Cells
}

OPEN ACCESS

Edited by:

Ariana Pintor,

University of Porto, Portugal

Reviewed by:

Đồng Hướng,

Ho Chi Minh City University of

Transport, Vietnam Junting Pan,

Institute of Agricultural Resources and

Regional Planning (CAAS), China

*Correspondence:

Florian Kretschmer

florian.kretschmer@boku.ac.at

Specialty section:

This article was submitted to Water and Wastewater Management,

a section of the journal

Frontiers in Environmental Science

Received: 29 September 2021

Accepted: 24 November 2021

Published: 21 February 2022

Citation:

Neugebauer G, Lichtenwoehrer P,

Huber F, Stoeglehner $G$ and Kretschmer F (2022) Potentials and Integrated Suitability Pre-assessment of Wastewater Treatment Plants as

Local Energy Cells.

Front. Environ. Sci. 9:785557. doi: $10.3389 /$ fenvs.2021.785557

\author{
Georg Neugebauer ${ }^{1}$, Peter Lichtenwoehrer ${ }^{1}$, Franz Huber ${ }^{2}$, Gernot Stoeglehner ${ }^{1}$ and \\ Florian Kretschmer ${ }^{2 *}$
}

${ }^{1}$ University of Natural Resources and Life Sciences, Vienna, Department of Landscape, Spatial and Infrastructure Sciences, Institute of Spatial Planning, Environmental Planning and Land Rearrangement, Vienna, Austria, ${ }^{2}$ University of Natural Resources and Life Sciences, Vienna,Department of Water, Atmosphere and Environment, Institute of Sanitary Engineering and Water Pollution Control, Vienna, Austria

In 2018 the European Union has recognized wastewater as a renewable energy source, particularly due to its thermal energy content. To create and further develop knowledge on the possible role that wastewater could play in the energy transition, this article pursues two objectives: 1) it presents an overview on the electric and thermal energy potentials available at the wastewater treatment plants (WWTPs) in the Central European area also taking their spatial context to adjacent settlement structures into account. 2) It introduces a small number of easy to apply criteria to (pre-)assess the suitability of WWTPs for being integrated into local energy (heat) supply concepts from an integrated perspective (considering energetic, spatial and environmental aspects). The investigations address the energy generation potentials of 3,315 WWTPs (with a treatment capacity of at least 5,000 population equivalents) in the area under survey. Analysis reveal, that notable amounts of heat ranging to almost $26 \mathrm{TWh} / \mathrm{a}$ are available. Their exploitation appears very promising, as investigations also show, that about $73 \%$ of the considered WWTPs are situated near or even within existing settlement structures implying very advantageous heat supply distances. Following the estimation of energy potentials, which is made available in the supplementary material, the presented suitability criteria can then be used to identify the most promising WWTPs in a specific regional/local context, in the investigated Central European area and beyond.

Keywords: energy transition, wastewater energy, heat recovery, integrated spatial and energy planning, renewable energy, climate change mitigation

\section{INTRODUCTION}

The European Green Deal (EC, 2019) aims at making the European Union (EU) climate neutral until the year 2050. For decarbonizing the energy systems, heating (and cooling) are of crucial importance. This is due to the fact that this sector already is and will continue be the biggest energy sector in the EU (EC, 2016). At least for today, it is still widely dominated by fossil energy sources. On the search for renewable heat sources wastewater has come into focus in recent years. Basically, one can distinguish between the chemical and the thermal energy content of wastewater (Frijns et al., 2013). The former can be accessed in the form of methane containing digester (biogas) produced during 
anaerobic digestion of sewage sludge. The latter can be recovered by heat exchangers situated in the wastewater flow. In this way, heat is then usually made available with an externally installed heat pump (Mo and Zhang, 2013). The application of biogas in combined heat and power (CHP) units to (partly) cover the internal electricity and heat demand has been common practice at many wastewater treatment plants (WWTPs) around the world for decades. Consequently, optimization of (electric) energy consumption and improved biogas generation to increase selfsufficiency of WWTPs has a long history in international research. In this context, Nowak et al. (2015) describe ways to optimize the energy balance of WWTPs. Schopf et al. (2018) introduce a tool to identify bioenergy potentials of WWTPs considering mass and energy flows of digester gas and sewage sludge. Yang et al. (2020) explore the correlations among wastewater internal energy, energy consumption and generation at WWTPs to model and predict energy selfsufficiency levels. Furthermore, alternative approaches for wastewater-based electricity generation at WWTPs have attracted increasing research intention in recent times. In this context one can mention hydropower installations (LlácerIglesias et al., 2021) and the application of microbial fuel cells (Munoz-Cupa et al., 2021).

In contrast, thermal energy provision through wastewater heat recovery still can be considered a rather novel approach in the field of wastewater and energy management. However, also in this field research efforts are constantly increasing. Wastewater heat gains, among others, more attention as excess heat source for district heating (Nielsen et al., 2020). It can be recovered at different locations - 1) in-house, 2) in-sewer, and 3) in the effluent of a WWTP - taking different technical solutions for its installation into account (Culha et al., 2015). Concerning 1) in-house solutions, research covers wastewater-based heating and cooling of multipurpose buildings (Cecconet et al., 2019), financial analysis of drain water heat recovery units on building level (Pochwat et al., 2020), and methodological developments to analyze the temporal evolution of domestic heat consumption (for hot water provision and space heating) and availability of wastewater heat in domestic drains (Spriet and McNabola, 2019). An overview of opportunities and threats of implementing drain water heat recovery units is provided by Kordana et al. (2019). In regard to 2) in-sewer wastewater heat recovery Piotrowska et al. (2020) summarize the current state of knowledge. Huber et al. (2020) present an approach to pre-assess the suitability of possible in-sewer sites for wastewater heat recovery. Referring to 3) in-effluent, Neugebauer et al. (2015) estimate the energy potential of (Austrian) WWTPs considering their spatial context. Additionally, Spriet et al. (2020) analyze spatial and temporal characteristics of wastewater-based heat supply. Different options to integrate WWTPs into local energy (heat) supply concepts are investigated by Kollmann et al. (2017) and Gruber-Glatzl et al. (2020). In line with academic research several countries have already released national guidelines to support the practical implementation of thermal use of wastewater (e. g. DWA-M114 (2020) in Germany, ÖWAV-AB 65 (2021) in Austria and AWEL (2010) in Switzerland). Finally, Hao et al. (2019) highlight the importance to further exploit the thermal energy content of wastewater instead of biogas related optimization. Elías-Maxil et al. (2014) argue in a comparable way, stating that the amount of heat recovered from urban (waste)water is still rather small compared to the available potential.

In the context of the above described activities and efforts, it also has to be highlighted, that in 2018 the EU recognized wastewater as a renewable energy source due to its content of thermal energy (Directive (EU) 2018/2001). When further thinking the presented academic and administrative discourse, the question about the specific role of wastewater in the energy transition becomes evident, and relating thereto, what basic information is needed to broadly develop this resource in a strategic approach. In our point of view, the first basis for answering this question is knowledge about the actual energy potentials of wastewater, and this not only from a single site perspective but rather from a trans-regional point of view. The second basis is a concept to identify suitable locations (WWTPs) to avoid unsustainable solutions. The recently completed Interreg Central Europe (CEU) project REEF 2W (https://www.interreg-central.eu/Content.Node/ REEF-2W.html) already made a first attempt in this regard. Our article now further elaborates the obtained project results. To provide the required (data) basis as support for developing and establishing wastewater as a renewable energy (heat) source, this article introduces 1) an overview of available energy (electricity and heat) potentials at Central European WWTPs also considering their specific spatial context in regard to surrounding settlement structures. The analysis includes all 3,315 WWTPs of a treatment capacity of at least 5,000 population equivalents (PEs) in the 47 NUTS 2 regions of the concerned project countries (in alphabetic order): Austria, Croatia, Czech Republic, the eastern and southern parts of Germany, and the northern parts of Italy. The work further indicates those regions in the area of survey with the highest heat power potential to be exploited. To identify, in the following, the most promising WWTPs to be integrated into local energy (heat) supply concepts in the different regions, this article also suggests 2) a small number of easy to apply criteria addressing energetic, spatial and environmental issues of wastewater energy/heat use. These criteria provide a quick impression on the general suitability of a WWTP to serve as a local energy (heat) cell. Concluding, this (pre-)assessment helps to identify the most promising WWTPs/locations in a region, worth being further investigated in a subsequent more detailed feasibility study. To better illustrate this integrated suitability pre-assessment, the presentation of the concept is supported by a case study.

\section{MATERIALS AND METHODS}

Materials and methods are presented for the estimation of energy potentials of WWTPs first, and for the integrated suitability preassessment of WWTPs as local energy cells second. Step one is applied on all WWTPs of the Central European project area, while step two is demonstrated on one Austrian case study. 


\subsection{Estimation of Energy Potentials}

The estimation of the available energy potentials considering the specific spatial context of a WWTP and its adjacent infrastructure is oriented on the approach and the assumptions presented by Neugebauer et al. (2015). In addition to wastewater heat recovery from the WWTPs effluents by the application of heat exchangers and heat pumps, electric and thermal energy generation from digester gas (biogas) combustion in combined heat and power (CHP) units is taken into account. These energetic potentials are analyzed in their spatial context, since an efficient heat supply strongly depends on the actual supply distance to the energy consumers.

\subsubsection{Energetic Context}

The core material to analyze the energetic context is the "waterbase" dataset on treatment plants reported under the European Urban Waste Water Treatment Directive (UWWTD data call 2019) and presented by the European Environmental Agency (EEA, 2019). The data is available in different formats (e. g. CSV, GIS-Shapefile, Microsoft Access database) and gives an overview on the WWTPs in all EU member countries including treatment capacity and current load. However, it does not include any information on the type of sewage sludge stabilization applied at the WWTPs (aerobic, anaerobic). Consequently, this information was added through expert judgement conducted on a country-specific basis. Hereby, the "waterbase" dataset was used as working base. In this dataset, which was transformed into an Excel-file, an additional column for anaerobic digestion (yes/no) was introduced. The related information was then entered manually by the local REEF $2 \mathrm{~W}$ partners, supported by local experts where needed. Taking into account a minimum capacity of 5,000 population equivalents (PEs) based on an analysis of relevant international guidelines presented in Huber et al. (2020), a total of 3,315 WWTPs situated in the REEF $2 \mathrm{~W}$ project area were used to estimate the energetic potentials.

The thermal energy potential from wastewater heat recovery $\left(\mathrm{P}_{\mathrm{WW}}\right)$ is estimated based on the current entering loads (LE) of the concerned WWTPs. Furthermore, we assume an average wastewater flow rate $\left(\mathrm{V}_{\mathrm{Ww}}\right)$ of $1501 / \mathrm{PE}^{*} \mathrm{~d}$ (which has to be converted into $\mathrm{m}^{3} / \mathrm{h}$ for calculation), a wastewater heat extraction in the WWTP effluents $(\Delta \mathrm{T})$ of $5 \mathrm{~K}$, and a heat capacity of (waste)water (c) of $1,16 \mathrm{kWh} / \mathrm{m}^{3 \star} \mathrm{K}$. To further derive the related energy supply $\left(\mathrm{ES}_{\mathrm{th}, \mathrm{HP}}\right)$ based on the thermal performance of a subsequent heat pump $\left(\mathrm{P}_{\mathrm{HP}}\right)$ we apply in accordance with Neugebauer et al. (2015) a coefficient of performance (COP) of four and an operation time of the heat pump $\left(t_{\mathrm{HP}}\right)$ of up to $4,500 \mathrm{~h} / \mathrm{a}$ (for settlement structures with mixed land uses).

$$
\begin{gathered}
P_{W W}=L E \times V_{W W} \times c \times \Delta T \\
P_{H P}=P_{W W} \times \frac{C O P}{(C O P-1)} \\
E S_{t h, H P}=P_{W W} \times t_{H P}
\end{gathered}
$$

The energy supply from digester gas $\left(\mathrm{ES}_{\mathrm{DG}}\right)$ is calculated for 720 WWTPs with anaerobic sludge digestion based on the current entering loads (LE) and average energy generation values (EGV) derived from Austrian WWTPs benchmarking investigations (Lindtner, 2008). We apply the following values for the electric $\left(\mathrm{EGV}_{\mathrm{el}}\right)$ and thermal $\left(\mathrm{EGV}_{\mathrm{th}}\right)$ energy generations from digester gas: $15 \mathrm{kWh}_{\mathrm{el}} / \mathrm{PE}^{\star} \mathrm{a}$, and $30 \mathrm{kWh}_{\mathrm{th}} / \mathrm{PE}^{\star} \mathrm{a}$, respectively.

$$
\begin{aligned}
E S_{e l, D G} & =L E \times E G V_{e l} \\
E S_{t h, D G} & =L E \times E G V_{t h}
\end{aligned}
$$

\subsubsection{Spatial Context}

The "waterbase" dataset also includes the coordinates for the exact spatial location of the WWTPs as relevant information for the spatial assessments. For all (energetic and spatial) analyses the provided shapefile format was preferred, as it simplifies the GIS based presentation of the analyses. Further core materials to analyze the spatial context are 1) Copernicus CORINE Land Cover data (EEA, 2021) which include the occurrence and spatial distribution of different settlement structures as an indication of potential heat consumers, and 2) EuroGeographics for the administrative boundaries (European Commission et al., 2018). Starting point for the spatial analyses are the administrative boundaries on NUTS 2 level (NUTS version of 2016). In accordance with the territorial focus of the REEF $2 \mathrm{~W}$ project, WWTPs located in 47 different regions across the five investigated countries were considered.

To acknowledge an economically reasonable heat supply distance (between the sites of heat recovery/generation and heat demand) each WWTP is categorized according to its spatial context in regard to the surrounding settlement structures. Starting from the WWTP as a point of heat source, overlays with three selected CORINE Land Cover categories "continuous urban fabric" (Code 111), "discontinuous urban fabric" (Code 112) and "industrial or commercial units" (Code 121), which are used as an indication of the presence of potential heat consumers, are calculated in radial supply distances of $150 \mathrm{~m}$ and $1,000 \mathrm{~m}$. Finally, each WWTP was categorized into one of the following three categories according to Neugebauer et al. (2015):

- "A- within the settlement": CORINE Land Cover settlement structures of at least $8,000 \mathrm{~m}^{2}$ within a range of $150 \mathrm{~m}$ and a minimum of 25 ha within a distance of $1,000 \mathrm{~m}$ to the WWTP.

- "B- near to the settlement": CORINE Land Cover settlement structures of at least 25 ha within a range between $150 \mathrm{~m}$ and $1,000 \mathrm{~m}$ away from the WWTP.

- "C - far from the settlement": Allocation of all remaining WWTPs, with a distance of more than $1,000 \mathrm{~m}$ to the settlement structures.

The categorization was further used to assign the heat recovery potential and thermal energy from wastewater, as well as thermal and electric energy from digester gas (biogas) combustion (in CHP units) in their specific spatial context. 
With respect to electricity supply, the spatial context between generation and consumption (transport loss) can be neglected.

\subsection{Procedure for the Integrated Suitability Pre-assessment}

The proposed suitability pre-assessment of WWTPs as local energy cells is designed for single cases and can be applied in specific regional/local contexts. The method is demonstrated on an Austrian case presented in Section 3.2. As illustrated in Figure 1, the approach involves an assessment in three categories 1) energetic, 2) spatial and 3) environmental.

Category 1) addresses the internal energy situation at the WWTP, considering both the electric and thermal energy perspectives. The assessment of energy consumption reveals, if the energy consumption of the wastewater and sludge treatment (aerobic or anaerobic) processes is efficient. The consideration of energy generation shows whether energy generation from digester gas is efficient and with the excess energy potential is shown whether additional energy (excess energy) can be provided by improved energy efficiency or increased energy generation (e. g. wastewater heat recovery). The list of criteria is shown in Table 1. The efficiency is assessed according to Austrian national benchmarks for (activated sludge) WWTPs according to Lindtner (2008). As these figures are influenced by local conditions, it is recommended to use country or region-specific benchmarks if available.
In category 2) the vicinity of the WWTP (external perspective) is taken into consideration with criteria related to the energy demand of spatial structures. To secure or create energy-efficient spatial and settlement structures, the issue of heat supply is of particular importance as a subject of integrated spatial and energy planning (Stoeglehner et al., 2016). Therefore, three criteria are proposed that can be used to make a rough assessment of the suitability for a grid-bound heat supply system. The first criterion takes into account the heating (and/or cooling) demand of different spatial structures like residential, commercial and industrial sites as well as agricultural sites like greenhouses, if present. With the second criterion, the energy demand is related to the area under consideration. The third criterion takes into account that the linear heating (and/or cooling) density is an important criterion for energy supply (Dochev et al., 2018), determining the feasibility of district heating (and cooling) systems and establishes a relation between the estimated energy demand and the supply distance (pipe length). Both density parameters mentioned are essential for assessing the suitability of an area for connection to a thermal network (Jalil-Vega and Hawkes, 2018).

To establish the criteria, first a supply area has to be zoned that is suitable for district heating. Of particular interest are areas with dense building stocks such as city, town or village centers, multistorey buildings or large energy consumers (ARGE QM Fernwärme, 2021). Second the energy demand is estimated with rough key figures or with more detailed models and

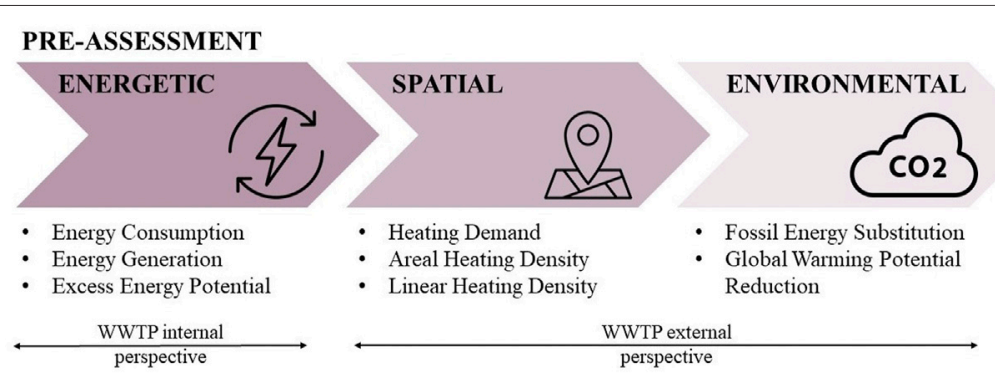

FIGURE 1 | Process Scheme for the Integrated Suitability Pre-Assessment (own illustration).

TABLE 1 | Criteria for the energetic pre-assessment (based on Lindtner, 2008).

\begin{tabular}{|c|c|c|c|c|c|}
\hline & Name & Definition & Unit & Categories & Graduation \\
\hline $\mathrm{EC}_{\text {th }}$ & Thermal Energy Consumption & $\begin{array}{l}\text { The amount of thermal energy consumed at the WWTP divided by population } \\
\text { equivalents (PE) }\end{array}$ & $\mathrm{kWh} / \mathrm{PE}_{120} \cdot \mathrm{a}$ & $\begin{array}{l}\leq 30 \\
>30\end{array}$ & $\begin{array}{l}\text { A } \\
\text { B }\end{array}$ \\
\hline $\mathrm{EC}_{\mathrm{el}}$ & Electric Energy Consumption & $\begin{array}{l}\text { The amount of electric energy consumed at the WWTP divided by population } \\
\text { equivalents (PE) }\end{array}$ & $\mathrm{kWh} / \mathrm{PE}_{120} \cdot \mathrm{a}$ & $\begin{array}{l}\leq 50 \\
>50\end{array}$ & $\begin{array}{l}\text { A } \\
B\end{array}$ \\
\hline$E G_{\text {th }}$ & Thermal Energy Generation & $\begin{array}{l}\text { The amount of thermal energy generated at the WWTP divided by population } \\
\text { equivalents (PE) }\end{array}$ & $\mathrm{kWh} / \mathrm{PE}_{120} \cdot \mathrm{a}$ & $\begin{array}{l}\geq 20 \\
<20\end{array}$ & $\begin{array}{l}\text { A } \\
B\end{array}$ \\
\hline$E G_{e l}$ & Electric Energy Generation & $\begin{array}{l}\text { The amount of electric energy generated at the WWTP divided by population } \\
\text { equivalents (PE) }\end{array}$ & $\mathrm{kWh} / \mathrm{PE}_{120} \cdot \mathrm{a}$ & $\begin{array}{l}\geq 10 \\
<10\end{array}$ & $\begin{array}{l}\text { A } \\
B\end{array}$ \\
\hline $\mathrm{EXC}_{\text {th }}$ & Thermal Excess Energy Potential & Difference between thermal energy generation and consumption & MWh/a & $\begin{array}{l}>0 \\
\leq 0\end{array}$ & $\begin{array}{l}A \\
B\end{array}$ \\
\hline $\mathrm{EXC}_{\mathrm{el}}$ & Electric Excess Energy Potential & Difference between electric energy generation and consumption & $\mathrm{MWh} / \mathrm{a}$ & $\begin{array}{l}>0 \\
\leq 0\end{array}$ & $\begin{array}{l}A \\
B\end{array}$ \\
\hline
\end{tabular}


supplemented with additional data (e.g. for industry, commercial sites) if applicable and available. Furthermore, the spatial distribution of the energy demand is considered and analyzed with the proposed density values according to Table 2 . This approach is focused on heating demand as excess electricity can be fed into the grid and thus the spatial context is of little relevance.

Category 3) evaluates environmental issues with criteria related to climate protection and the decarbonization of local energy supply systems (WWTP external perspective): The substitution potential of fossil energy addresses the replacement of fossil energies in the WWTPs surroundings by energy from wastewater and the reduction of the global warming potential expresses the associated savings in $\mathrm{CO}_{2}$ emissions in relation to the current (fossil) energy supply situation in the region/location under consideration according to Table 3.

The potential for substituting fossil with renewable energy is derived from the WWTPs energy balance. In the electrical balance, the supply from the combined heat and power plant minus the current electricity purchase from the grid is compared with the electrical energy consumption of the WWTP. For the heat side, the supply by means of combustion of the sewage gas and the use of wastewater energy are compared with the WWTPspecific consumption. The reduction in $\mathrm{CO}_{2}$ emissions is expressed by comparing the emissions in the scenario under consideration with those of a reference system (e.g. natural gas supply for thermal energy as well as national electricity mix). Specific emission factors (see Table 4) are used for the calculations which can be adapted to the respective specific local context.
The Environment Agency Austria provides three different emission factors (Kranzl, 2018; UBA, 2019): The first emission factor "Electricity Mix Austria" is calculated on the basis of the Austrian power plant inventory, but also takes into account the emission factors of electricity generation in the countries from which electricity is imported. With the second emission factor "Power Plant Portfolio Austria", only the electricity generation plants on Austrian territory are taken into account according to the territorial principle. The third emission factor "Eco-Label Green Electricity" represents an electricity generation mix entirely from renewable energy sources.

\section{RESULTS}

\subsection{Available Energy Potentials in Spatial Context}

In total 3,315 WWTPs of at least 5000 PEs capacity are located in the research area, which comprises 47 NUTS2 regions from Austria, Czech Republic, Germany, Croatia and Italy. The spatial distribution of all WWTPs in the research area is visualized in Figure 2. It is apparent, that due to the sole concentration on the Interreg CEU program area, only parts of Germany (eastern and southern part) and Italy (northern part) are considered.

Table 5 shows an overview of the WWTP inventory (rounded values for the treatment capacities and entering loads). In absolute numbers most WWTPs can be found in the concerned parts of Germany (DE), followed by the concerned parts of Italy (IT), Austria (AT), Czech Republic (CZ) and Croatia (HR). Consequently, also the treatment

TABLE 2 | Criteria for the spatial pre-assessment (based on ARGE QM Fernwärme, 2021).

\begin{tabular}{|c|c|c|c|c|c|}
\hline & Name & Definition & Unit & Categories & Graduation \\
\hline \multirow{2}{*}{$H D_{\text {ext }}$} & WWTP External Heating & Heating demand in the vicinity of the WWTP & $\mathrm{MWh} / \mathrm{a}$ & $>0$ & A \\
\hline & Demand & & & $=0$ & $\mathrm{~B}$ \\
\hline \multirow[t]{2}{*}{$\mathrm{HD}_{\text {area }}$} & (Areal) Heating density & Heating demand in relation to the area under consideration & MWh/ha*a & $\geq 500$ & A \\
\hline & & & & $<500$ & $\mathrm{~B}$ \\
\hline \multirow[t]{2}{*}{$H D_{\text {lin }}$} & Linear Heating density & Heating demand in the vicinity of the WWTP divided by the estimated pipe & $\mathrm{MWh} / \mathrm{m}^{\star} \mathrm{a}$ & $\geq 0.7$ & A \\
\hline & & length & & $<0.7$ & $\mathrm{~B}$ \\
\hline
\end{tabular}

TABLE 3 | Criteria for the environmental pre-assessment (own assumptions).

\begin{tabular}{|c|c|c|c|c|c|}
\hline & Name & Definition & Unit & Categories & Graduation \\
\hline \multirow[t]{2}{*}{$\mathrm{SP}_{\mathrm{th}}$} & Substitution Potential of Fossil & Renewable thermal excess energy in relation to WWTP internal thermal & $\%$ & $>100$ & A \\
\hline & Thermal Energy & $\begin{array}{l}\text { energy consumption (potential for the substitution of WWTP external fossil } \\
\text { thermal energy demand) }\end{array}$ & & $\leq 100$ & $\mathrm{~B}$ \\
\hline \multirow[t]{2}{*}{$\mathrm{SP}_{\mathrm{el}}$} & Substitution Potential of Fossil & Renewable electricity excess energy in relation to WWTP internal electric & $\%$ & $>100$ & A \\
\hline & Electricity & $\begin{array}{l}\text { energy consumption (potential for the substitution of WWTP external fossil } \\
\text { electricity demand) }\end{array}$ & & $\leq 100$ & $\mathrm{~B}$ \\
\hline \multirow[t]{2}{*}{$G W P_{\text {th }}$} & Reduction of Global Warming & $\mathrm{CO}_{2}$ emissions reduction for thermal energy provided by the WWTP & $\mathrm{t} \mathrm{CO}_{2 \text {-equ }}$ & $>0$ & A \\
\hline & Potential (thermal) & compared to a standard reference system (heat supply from natural gas) & & $\leq 0$ & $\mathrm{~B}$ \\
\hline \multirow[t]{2}{*}{$G_{W} P_{e l}$} & Reduction of Global Warming & $\mathrm{CO}_{2}$ emissions reduction for electric energy provided by the WWTP & $\mathrm{t} \mathrm{CO}_{2 \text {-equ }}$ & $>0$ & A \\
\hline & Potential (electric) & compared to a standard reference system (electricity from the grid - national & & $\leq 0$ & $\mathrm{~B}$ \\
\hline
\end{tabular}


TABLE 4 | $\mathrm{CO}_{2}$-emission factors for different energy sources (UBA, 2019).

Energy carrier

$\mathrm{CO}_{2}$ emission facto

(kg $\mathrm{CO}_{2 \text {-equ. }} / \mathrm{kWh}$ )

Natural gas (reference heating system)

Electricity Mix Austria

0.271

0.258

0.196

Power Plant Portfolio Austria

Eco-Label "Green Electricity"

capacity and entering load are highest for Germany, the same applies for the absolute number of WWTPs with anaerobic digestion. The relative shares of WWTPs with anaerobic digestion (related to the WWTPs capacities) are the highest for Austria, while for Croatia anaerobic digestions still seem rather underrepresented. These findings underline certain development potentials for anaerobic digestion (biogas generation) in the respective countries.

In a next step, the total number of WWTPs for each country (inventory) was further split according to their spatial context. The results of the WWTPs spatial inventory are presented in Table 6. From this data, it is apparent that about $35 \%(1,166)$ of all considered WWTPs in the research area are located directly within a settlement and another $38 \%(1,248)$ near to a settlement. In other words, approximately $73 \%(2,414)$ of the WWTPs are located within appropriate heat supply distances. Only $27 \%$ of the WWTPs are situated far from a settlement and therefore appear less suitable for local heat supply. Further, the highest share of A-categorized WWTPs was detected in the Czech Republic (60\%), followed by Austria (43\%) and Germany (32\%) whereas the highest share of C-categorized WWTPs were found in Germany (32\%), Austria (29\%) and Croatia (25\%). Croatia also comprises the highest share of B-categorized plants (49\%).

Table 7 shows the estimated wastewater heat recovery potentials (in $\mathrm{MW}$ ) and the thermal energy from wastewater (in GWh/a) for each country considering the spatial context of the WWTPs. The results reveal the large amounts of thermal energy available in the wastewater, which in total corresponds to about $3,944 \mathrm{MW}$ of heat recovery potential and around $23,667 \mathrm{GWh} / \mathrm{a}$ of thermal energy. Regarding the three spatial categories, the allocation of available energy shows high shares of available energy in A-categorized WWTPs. In total, heat recovery potential $(2,257 \mathrm{MW})$ and thermal energy $(13,544 \mathrm{GWh} / \mathrm{a})$ from wastewater in A-categorized WWTPs represent more than

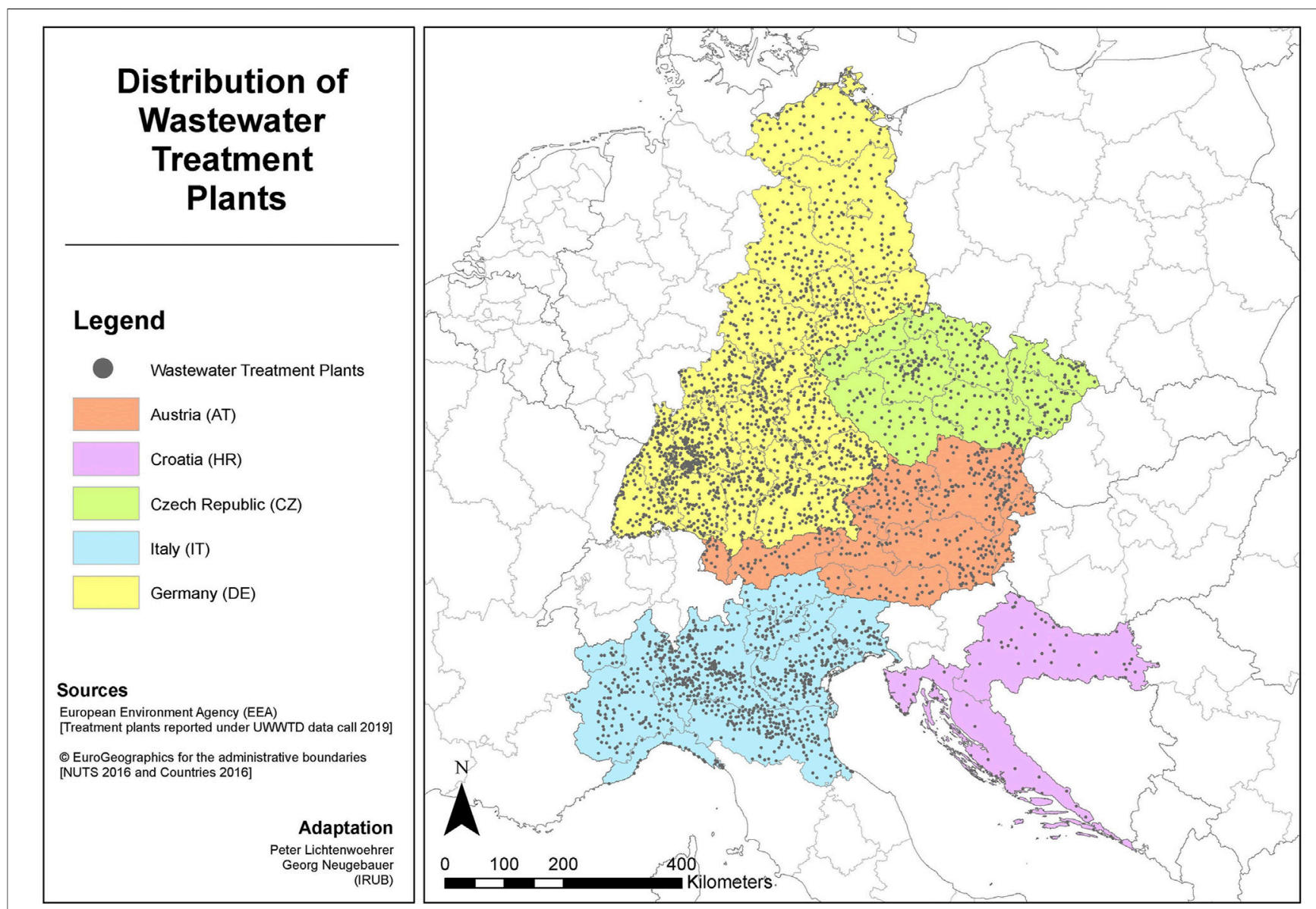

FIGURE 2 | Distribution of WWTPs in the research area (own illustration). 
TABLE 5 | Technical inventory of WWTPs per country (REEF 2W eBook, s.a. adapted).

\begin{tabular}{|c|c|c|c|c|}
\hline Country & WWTPs (no.) & WWTPs capacity (PE) & $\begin{array}{l}\text { WWTPs } \\
\text { entering load (PE) }\end{array}$ & $\begin{array}{l}\text { WWTPs with anaerobic } \\
\text { digestion (no.) }\end{array}$ \\
\hline AT & 403 & $20,832,000$ & $14,263,000$ & 154 \\
\hline CZ & 354 & $14,706,000$ & $9,006,000$ & 91 \\
\hline DE (partly) & 1,580 & $67,941,000$ & $50,671,000$ & 377 \\
\hline $\mathrm{HR}$ & 80 & $3,349,000$ & $2,169,000$ & 3 \\
\hline IT (partly) & 898 & $47,265,000$ & $32,703,000$ & 95 \\
\hline CEU area & 3,315 & $154,093,000$ & $108,812,000$ & 717 \\
\hline
\end{tabular}

TABLE 6 | Spatial context of WWTPs for each country (own illustration).

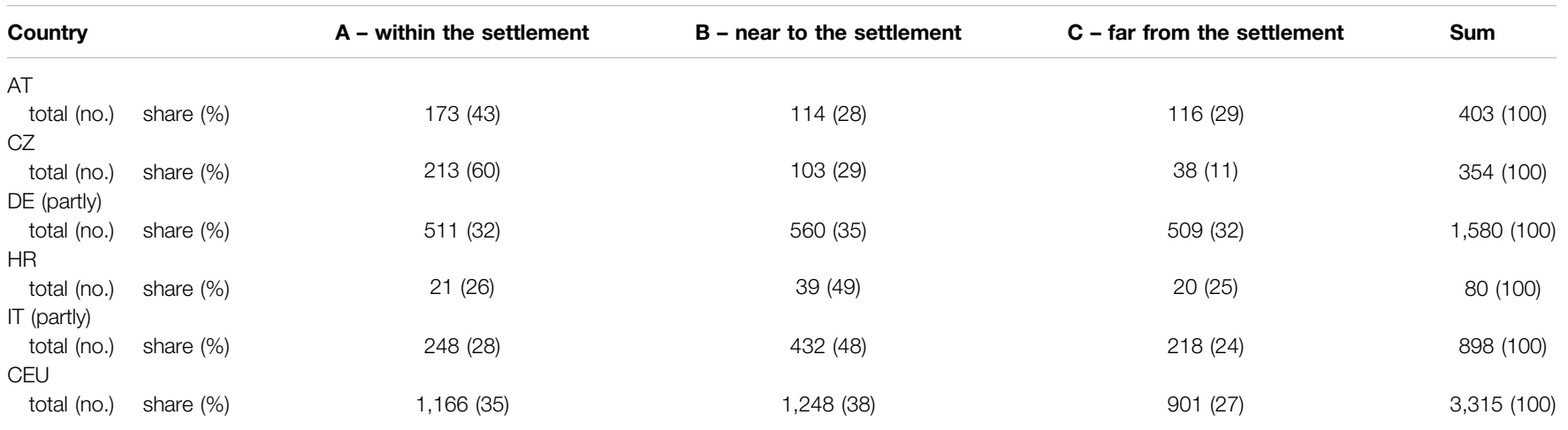

TABLE 7 | Estimation of wastewater heat recovery potentials (MW) and thermal energy from wastewater (GWh/a) in context to the adjacent settlement structures (own illustration).

\begin{tabular}{|c|c|c|c|c|c|}
\hline & Country & A - within the settlement & B - near to the settlement & C - far from the settlement & Sum \\
\hline \multirow[t]{6}{*}{ Heat recovery potential from wastewater (MW) } & AT & 340 & 90 & 87 & 517 \\
\hline & CZ & 217 & 80 & 29 & 326 \\
\hline & DE (partly) & 1,023 & 444 & 369 & 1,836 \\
\hline & $\mathrm{HR}$ & 40 & 26 & 13 & 79 \\
\hline & IT (partly) & 637 & 365 & 184 & 1,186 \\
\hline & CEU area & 2,257 & 1,005 & 682 & 3,944 \\
\hline \multirow[t]{6}{*}{ Thermal energy from wastewater (GWh/a) } & AT & 2,040 & 539 & 524 & 3,102 \\
\hline & $\mathrm{CZ}$ & 1,305 & 480 & 174 & 1,959 \\
\hline & DE (partly) & 6,140 & 2,666 & 2,215 & 11,021 \\
\hline & $\mathrm{HR}$ & 239 & 157 & 75 & 472 \\
\hline & IT (partly) & 3,820 & 2,187 & 1,105 & 7,113 \\
\hline & CEU area & 13,544 & 6,029 & 4,093 & 23,667 \\
\hline
\end{tabular}

twice the B-categorized potential $(1,005 \mathrm{MW})$ and thermal energy $(6,029 \mathrm{GWh} / \mathrm{a})$. Finally, less than a sixth of the total available energy are allocated to C-categorized treatment plants, $682 \mathrm{MW}$ and 4,093 GWh/a, respectively.

Table 8 clearly shows that the total available energy from digester gas (thermal and electric) is significantly lower than thermal energy from wastewater, which is true for all countries and even for every single spatial category of each country. However, the analysis further reveals highest thermal (th) and electric (el) energy potentials in A-categorized WWTPs (1,432 $\mathrm{GWh}_{\mathrm{th}} / \mathrm{a}$ and $\left.716 \mathrm{GWh}_{\mathrm{el}} / \mathrm{a}\right)$ compared to B-categorized (413 GWh $\mathrm{Gh}_{\mathrm{th}} / \mathrm{a}$ and $\left.208 \mathrm{GWh}_{\mathrm{el}} / \mathrm{a}\right)$ and C-categorized plants (294 GWh $\mathrm{Gh}_{\mathrm{th}} / \mathrm{a}$ and $\left.148 \mathrm{GWh}_{\mathrm{el}} / \mathrm{a}\right)$. In Austria for instance, almost five times more energy $\left(243 \mathrm{GWh}_{\mathrm{th}} / \mathrm{a}\right.$ and 122 $\mathrm{GWh}_{\mathrm{el}} / \mathrm{a}$ ) can be allocated to A-categorized treatment plants than to
B-categorized ( $50 \mathrm{Wh}_{\mathrm{th}} / \mathrm{a}$ and $25 \mathrm{GWh}_{\mathrm{el}} / \mathrm{a}$ ) or C-categorized plants (47 $\mathrm{GWh}_{\text {th }} / \mathrm{a}$ and $24 \mathrm{GWh}_{\mathrm{el}} / \mathrm{a}$ ).

The results reveal significant potentials for the utilization of thermal (excess) energy from WWTPs. Obviously, depending on the location and the energy potential certain WWTPs appear more promising. Hence, we further investigated the spatial context of the WWTPs and identified the most promising NUTS2 regions with respect to their total heat power potentials and the spatial contexts of the WWTPs. Figure 3 color-codes the most promising regions. Simultaneously, the share (relative to the total number of WWTPs in the NUTS2 region) of the spatial categories A, B, C are visualized in the pie charts for each NUTS2 region.

It can be concluded that almost the entire part of northern Italy as well as certain parts of Germany show the highest heat power 
TABLE 8 | Estimation of thermal and electric energy generation from digester gas (in GWh/a) in context to the adjacent settlement structures (own illustration).

\begin{tabular}{|c|c|c|c|c|c|}
\hline & Country & A - within the settlement & B - near to the settlement & C - far from the settlement & Sum \\
\hline \multirow[t]{6}{*}{ Thermal energy generation from digester gas (GWh/a) } & AT & 243 & 50 & 47 & 340 \\
\hline & $\mathrm{CZ}$ & 133 & 48 & 17 & 198 \\
\hline & DE (partly) & 667 & 225 & 176 & 1,068 \\
\hline & $\mathrm{HR}$ & 23 & 3 & 0 & 26 \\
\hline & IT (partly) & 366 & 87 & 54 & 507 \\
\hline & CEU area & 1,432 & 413 & 294 & 2,139 \\
\hline \multirow[t]{6}{*}{ Electric energy generation from digester gas (GWh/a) } & AT & 122 & 25 & 24 & 171 \\
\hline & $\mathrm{CZ}$ & 66 & 24 & 9 & 99 \\
\hline & DE (partly) & 333 & 113 & 88 & 534 \\
\hline & $\mathrm{HR}$ & 12 & 2 & 0 & 14 \\
\hline & IT (partly) & 183 & 44 & 27 & 254 \\
\hline & CEU area & 716 & 208 & 148 & 1,072 \\
\hline
\end{tabular}

potentials, followed by regions in the east of Austria. Lowest potentials are detected in the Czech Republic and Croatia. The results of the total heat power potential need to be interpreted with caution, since the total amount is used in the visualization of the map. Therefore, the pie charts offer further opportunities to assess the regions. Taking a closer look at the pie charts, the Czech Republic for instance contains a relative high share of WWTPs within the settlement (A-categorized treatment plants) which also indicates rather beneficial framework conditions for heat supply. In total, in CEU $1,072 \mathrm{GWh} / \mathrm{a}$ of electric and $25,806 \mathrm{GWh} / \mathrm{a}$ of thermal energy can be generated, leading to 3,4 million tons of GWP-reductions compared to thermal natural gas supplies taking into account national emission factors (Koffi et al., 2017) for the electricity used to operate the heat pumps. How these potentials
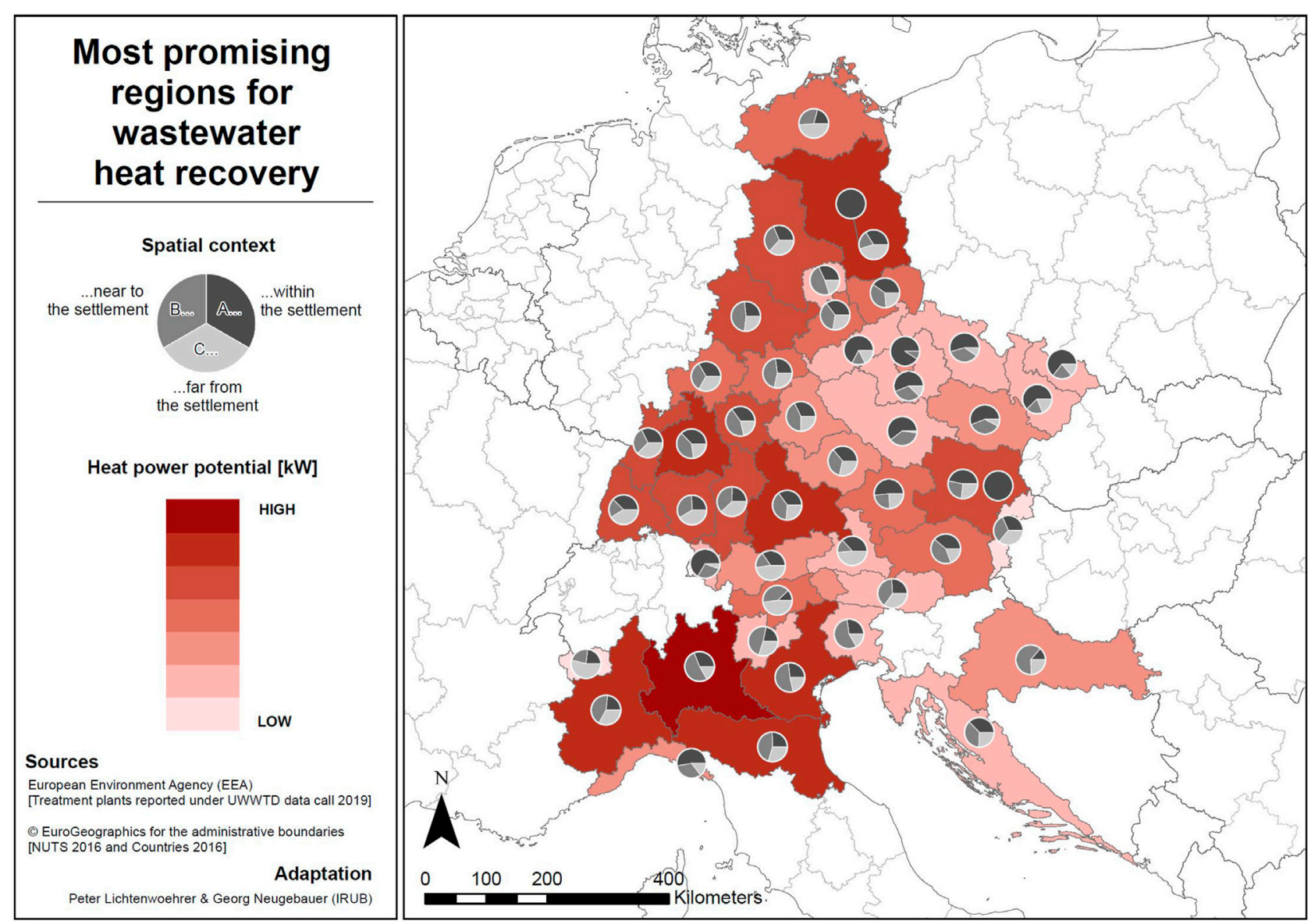

FIGURE 3 | NUTS2 regions with the highest heat power potential and its spatial context (own illustration). 
TABLE 9 | Key technical and operational data of the case study WWTP (Zach et al., 2019 adapted).

\begin{tabular}{|c|c|c|}
\hline Parameter & Value & Unit \\
\hline Thermal energy consumption (2016) & 2,309 & $\mathrm{MWh} / \mathrm{a}$ \\
\hline of which tempering of the digester towers & 2,020 & $\mathrm{MWh} / \mathrm{a}$ \\
\hline Thermal energy generation from digester gas (2016) & 2,848 & $\mathrm{MWh} / \mathrm{a}$ \\
\hline Electric energy consumption (2016) & 2,041 & $\mathrm{MWh} / \mathrm{a}$ \\
\hline Electric energy generation from digester gas (2016) & 3,744 & $\mathrm{MWh} / \mathrm{a}$ \\
\hline Average wastewater flow (2016/2017) & $6,000,000$ & $\mathrm{~m}^{3} / \mathrm{a}$ \\
\hline Average wastewater temperature (2016/2017) & 14,3 & ${ }^{\circ} \mathrm{C}$ \\
\hline
\end{tabular}

can be further assessed case by case, is demonstrated in the following section on behalf of an Austrian case study.

\subsection{Integrated Suitability Pre-Assessment of WWTPs as local energy cells}

To prove and illustrate the practicability of the presented approach the pre-assessment is applied to the Austrian REEF $2 \mathrm{~W}$ case study site. The WWTP is situated in "Wallern an der Trattnach", a small municipality in the province of Upper Austria. According to the concerned wastewater utility RHV (s.a.), 2021 the current treatment capacity is 74,000 PE, the average load amounts to 50,000 PE. The WWTP is equipped with mechanical pre-treatment (screens, combined sand and grease trap, primary clarifier) and a biological wastewater treatment stage (activated sludge process in two parallel aeration basins and four secondary clarifiers). Excess sludge stabilization takes place in two digestion towers. To increase the digester gas yield, liquid waste from WWTP external sources is used for co-fermentation. The neighboring settlements are "Wallern an der Trattnach" itself and "Bad Schallerbach". Statistik Austria (2021a, 2021b) assigns the former with 3,085 inhabitants and an area of $14.6 \mathrm{~km}^{2}$, the latter with 4,209 inhabitants and $8.5 \mathrm{~km}^{2}$. Both municipalities are subsequently connected to the WWTP, the minimum distance between the settlements and the WWTP is around $2 \mathrm{~km}$. Table 9 summarizes the key technical and operational parameters of the WWTP. Figure 4 illustrates the spatial context of the case study WWTP to its surrounding settlement structures. Further information in regard to integrated energy and spatial analysis at this WWTP is presented in Lichtenwoehrer et al. (2021).

The current energy consumption and the existing energy supply situation of the case study WWTP can be characterized with the values listed in Table 9. In addition, the basis for the estimation of the wastewater energy potentials is shown.

On the basis of the technical parameters for the case study WWTP presented in Table 9, the following results can be obtained for the pre-assessment of the suitability as a local energy cell, taking into account 1) energetic, 2) spatial and 3) environmental criteria. The calculated indicators and their classification according to the categories presented in Tables 1-3 are shown in Table 10.

1) Energetic criteria: Based on a current load of 50,000 PE, a total annual thermal energy consumption of 2,309 MWh/a results in a specific thermal energy consumption of $46.2 \mathrm{kWh} / \mathrm{PE}^{\star} \mathrm{a}$. This value is higher than the defined threshold value which implies optimization potential in regard to thermal energy use and is reflected in a classification in category B. The electric energy balance shows a different picture: A total annual electric energy consumption of 2,041 MWh/a results in a specific electric energy consumption of $40.8 \mathrm{kWh} / \mathrm{PE}^{\star} \mathrm{a}$ in relation to the actual entering load. This value lies just below the threshold value derived from Austrian WWTPs benchmarking results and leads to a class A rating.

The current thermal energy generation from digester gas combustion $(2,848 \mathrm{MWh} / \mathrm{a})$ is reflected in a specific thermal energy generation of $57 \mathrm{kWh} / \mathrm{PE}^{\star} \mathrm{a}$ in relation to the actual entering load. The current electric energy generation from the combustion of digester gas $(3,744 \mathrm{MWh} / \mathrm{a})$ results in a specific electric energy generation of $74.9 \mathrm{kWh} / \mathrm{PE}^{*} \mathrm{a}$. Both values are significantly higher than the defined threshold values, which can be explained by the application of co-digestion and leads in both cases to a classification in class $\mathrm{A}$.

The comparison of energy consumption and generation results in surpluses in the annual electric energy balance. For long periods of the year, sufficient electricity can be provided for the WWTPs processes, only at a few times it is necessary to purchase electricity from the grid. The heat balance also shows surpluses that can be used to supply consumers outside the WWTP. Significant surpluses can be achieved in particular by tapping into the so far unused wastewater heat. Taking into account the thermal wastewater energy potentials, an even significantly higher result can be achieved (21,408 MWh/a). However, the use of wastewater heat by means of heat pumps also implies additional electricity demand, which adds up to a total of $6,681 \mathrm{MWh} / \mathrm{a}$.

2) Spatial Criteria: By means of spatial analyses of the WWTPs surroundings, energy zones can be delineated that can be considered for a potential district heating supply. In the case study, 11 energy zones with a total area of 78 ha are considered, taking into account the location of municipal infrastructure facilities as potential heat consumers. With a model-based approach, a total heat demand in the vicinity of the WWTP in the amount of 20,300 MWh/a can be determined (Lichtenwoehrer et al., 2021). With the presence of potential heat consumers in the WWTPs surroundings, a classification in category $\mathrm{A}$ is applied. On average, the heat demand density is about $260 \mathrm{MWh} / \mathrm{ha}^{\star} \mathrm{a}$ (category B), whereby clear differences 


\section{Case study wastewater treatment plant RHV Trattnachtal \\ - Wastewater Treatment Plants \\ $\square$ CORINE Land Cover within $150 \mathrm{~m}$ radius CORINE Land Cover within $1,000 \mathrm{~m}$ radius \\ $\square 150 \mathrm{~m}$ radius \\ $\square, 000$ m radius \\ CORINE Land Cover categories: \\ 111: Continuous urban fabric 112: Discontinuous urban fabric 121: Industrial or commercial units \\ Sources \\ European Environment Agency (EEA) \\ [Treatment plants reported under UWWTD data call 2019] \\ European Union (2021) Copernicus Land Monitoring \\ Service 2018, European Environment Agency (EEA) \\ Base map @ OpenStreetMap (and) contributors \\ (www.openstreetmap.org) \\ Adaptation \\ Peter Lichtenwoehrer \& Georg Neugebauer (IRUB)}

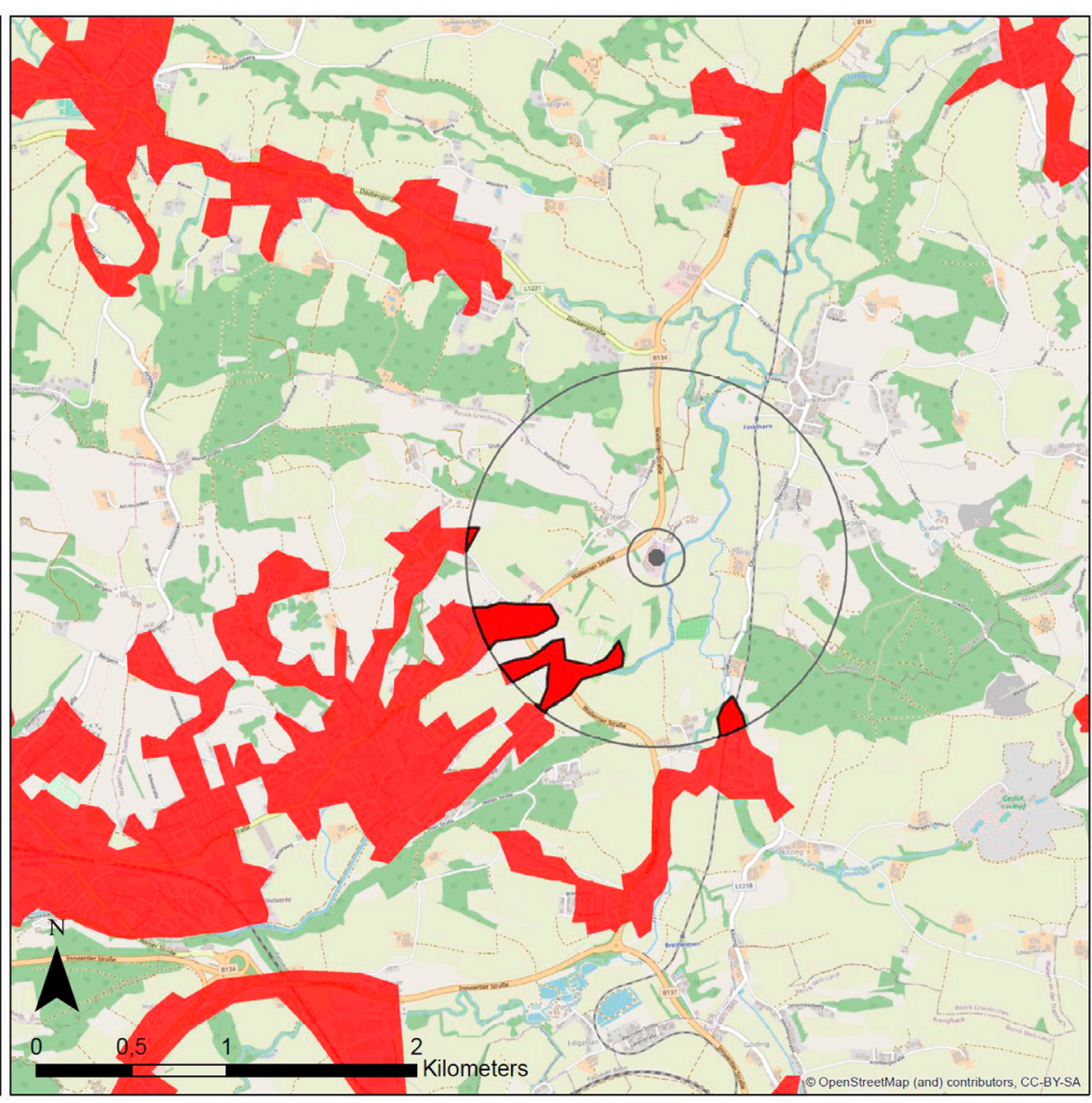

FIGURE 4 | Location of the case study WWTP including its spatial context (own illustration).

TABLE 10 | Results of the case study pre-assessment (own illustration).

\begin{tabular}{|c|c|c|c|c|c|}
\hline & Name & Value & Unit & Category & Graduatior \\
\hline \multicolumn{6}{|c|}{ Energetic context (WWTP internal perspective) } \\
\hline $\mathrm{EC}_{\text {th }}$ & Thermal Energy Consumption & 46.2 & $\mathrm{kWh} / \mathrm{PE}_{120} \cdot \mathrm{a}$ & $>30$ & $\mathrm{~B}$ \\
\hline $\mathrm{EC}_{\mathrm{el}}$ & Electric Energy Consumption & 40.8 & $\mathrm{kWh} / \mathrm{PE}_{120} \cdot \mathrm{a}$ & $\leq 50$ & A \\
\hline$E G_{\text {th }}$ & Thermal Energy Generation & 57,0 & $\mathrm{kWh} / \mathrm{PE}_{120} \cdot \mathrm{a}$ & $\geq 20$ & A \\
\hline$E G_{e l}$ & Electric Energy Generation & 74.9 & $\mathrm{kWh} / \mathrm{PE}_{120} \cdot \mathrm{a}$ & $\geq 10$ & A \\
\hline $\mathrm{EXC}_{\mathrm{th}}$ & Thermal Excess Energy Potential & 1,703 & $\mathrm{MWh} / \mathrm{a}$ & $>0$ & A \\
\hline $\mathrm{EXC}_{\mathrm{el}}$ & Electric Excess Energy Potential & 539 & $\mathrm{MWh} / \mathrm{a}$ & $>0$ & A \\
\hline \multicolumn{6}{|c|}{ Spatial context (WWTP external perspective) } \\
\hline$H D_{\text {ext }}$ & WWTP External Heating Demand & 20,300 & $\mathrm{MWh} / \mathrm{a}$ & $>0$ & A \\
\hline$H D_{\text {area }}$ & (Areal) Heating Density & 260 & $\mathrm{MWh} / \mathrm{ha}^{\star} \mathrm{a}$ & $<500$ & $\mathrm{~B}$ \\
\hline$H D_{\text {lin }}$ & Linear Heating Density & 1.17 & $\mathrm{MWh} / \mathrm{m}^{\star} \mathrm{a}$ & $\geq 0.7$ & A \\
\hline \multicolumn{6}{|c|}{ Environmental context (WWTP external perspective) } \\
\hline $\mathrm{SP}_{\text {th }}$ & Substitution Potential of Fossil Thermal Energy & 927 & $\%$ & $>100$ & A \\
\hline $\mathrm{SP}_{\mathrm{el}}$ & Substitution Potential of Fossil Electricity & 57 & $\%$ & $\leq 100$ & $\mathrm{~B}$ \\
\hline$G W P_{\text {th }}$ & Reduction of Global Warming Potential (thermal) & 5,176 & t $\mathrm{CO}_{2-\text { equ }}$ & $>0$ & A \\
\hline $\mathrm{GWP}_{\mathrm{el}}$ & Reduction of Global Warming Potential (electric) & $-46 /-745$ & $\mathrm{t} \mathrm{CO}_{2 \text {-equ }}$ & $\leq 0$ & $\mathrm{~B}$ \\
\hline
\end{tabular}


occur between compact settlement structures with higher densities and parts of the potential district heating supply area with moderate building densities. A possible expansion of the district heating network over $17,4 \mathrm{~km}$ thus results in a linear heat density in the order of $1.17 \mathrm{MWh} / \mathrm{m}$, which can be considered suitable for a district heating supply and is expressed with a category A classification.

3) Environmental Criteria: From an environmental perspective, it is evident that significant heat surpluses can be achieved by using wastewater energy as a renewable energy source to provide heat. Compared to the WWTP internal heat demand, more than nine times the thermal energy can be provided $(21,408 \mathrm{MWh} / \mathrm{a})$, including the heat potential from wastewater $(18,560 \mathrm{MWh} / \mathrm{a})$ and the heat from the combustion of the digester gas $(2,848 \mathrm{MWh} / \mathrm{a})$. This substitution potential is expressed with a classification in category A. However, in order for wastewater heat to be tapped by means of heat exchangers and heat pumps, additional electrical energy is required (4,640 MWh/a), which can no longer be provided in its entirety with electricity from the CHP unit.

The renewable heat provided by the WWTP which is not used to meet internal demands (19,099 MWh/a) can be used to substitute fossil energy in the WWTPs surroundings and thus achieve significant savings in greenhouse gas emissions compared to a reference heat supply system (e.g. natural gas in the case study). Savings in the amount of 5,176 tons of $\mathrm{CO}_{2}-$ eqivalents are evaluated with a classification in category A. For the assessment of the actual greenhouse gas emissions savings, the electricity mix used for the operation of the heat pump is decisive. Calculated with the average Austrian electricity supply, emissions form heat pump operation amount to 745 tons of $\mathrm{CO}_{2}$ equivalent per year, with a $100 \%$ renewable electricity mix, the emissions are only in the amount of 46 tons of $\mathrm{CO}_{2}$ equivalent per year. Depending on the electricity mix used, savings in greenhouse gas emissions in a range of 4,431 to 5,130 tons of $\mathrm{CO}_{2}$ equivalent can be achieved if a heating system based on natural gas supply is replaced.

\section{DISCUSSION}

\subsection{Interpretation of Results \\ 4.1.1 Available Energy Potentials}

The investigations confirm the availability of large quantities of thermal energy at the WWTPs of the CEU area. In addition, a vast majority of these heat sources is situated in close range to existing settlement structures, implying short and thus promising heat supply distances. Consequently, the widely untapped heat potential from WWTPs (mainly accessible through wastewater heat recovery) can certainly provide an additional and promising option for local heat supply.

Today, digester gas (biogas) is most commonly combusted in combined heat and power systems, but in practice, at least the thermal energy is often not fully used. The electric generation potential can reduce the purchased electricity demand, and depending on the regional mix of energy sources might increase the share of renewable electricity and reduce the global warming potential of the WWTP. The thermal energy provided from biogas combustions is partly used internally, partly considered as excess heat together with the wastewater energy from the effluent of the WWTPs. However, apart from a quantitative aspect one should keep in mind the qualitative aspects of the heat sources. Due to the combustion digester gas-based heat has a higher temperature level than wastewater heat recovered by a heat pump. Consequently, the appropriate application of the available heat source should also gain more attention in the context of energy efficiency. Kretschmer et al. (2021) investigate this issue at a location in Austria, where the WWTP internal (low temperature) heat demand shall be met by wastewater heat recovery from the effluent to make the entire heat from digester gas combustion available to be fed into the municipal (high temperature) district heating network. The feasibility study provided very promising results so that implementation is on the way.

However, on the following examples the dimensions of the estimated energy potential can be made more tangible: First, we assume an average per capita heat requirement for space heating and hot water (including heat losses in the system) for the investigated regions of $2.5 \mathrm{MWh} / \mathrm{a}$. The energy analysis shows that the total estimated thermal energy supplied by wastewater heat pumps is around $23,700 \mathrm{GWh}$ /a. Consequently, around 9.5 million people could be supplied with recovered heat from wastewater. Second, according to Lindtner (2008), the average thermal energy consumption of a WWTP can be up to $30 \mathrm{kWh} /$ $P^{\star} a$. The inventory of WWTPs in the CEU area implies a WWTP inflow load of approximately 109 million PE, which would result in a (theoretic) total heat demand of about 3,300 GWh/a. Reconsidering the total estimated thermal energy supplied by wastewater heat pumps of about $23,700 \mathrm{GWh} / \mathrm{a}$, theoretically, the heat demand of all WWTPs in the CEU area could be met at least 7 times. Already these rather simple calculations, and even without considering the heat potential from digester gas combustion, clearly indicate large quantities of surplus heat available at the CEU WWTPs. The fact, that almost $75 \%$ of the WWTPs benefit from rather short supply distances to the surrounding heat consumers further emphasizes the great opportunities of WWTPs to be developed as local energy cells.

Yet, it has to be considered that the source of the electricity to run the heat pumps is of crucial importance for the reduction of the global warming potential. If the European electricity mix is applied to run the heat pumps, wastewater energy has the same global warming potential than heat generated from natural gas. But if renewable electricity is applied, the global warming potential of the generated heat can be reduced by a factor 72 (!) (Kollmann et al., 2017). Also the amount of renewable electricity needed has to be taken into account. To fully tap the $23,700 \mathrm{GWh} / \mathrm{a}$ of heat in the 3,315 WWTPs in CEU, around $6,000 \mathrm{GWh} / \mathrm{a}$ (depending on the coefficient of performance of the heat pump) of additional electricity is needed. This corresponds to the yearly energy generation of 850 standard on-shore wind power plants of 
$3 \mathrm{MW}$ power each. In other words, on average four WWTPs would require one spin wheel.

\subsubsection{Pre-assessment of the Case Study WWTP}

By means of the proposed methodology, the question of what role a WWTP can play as a local energy cell in a sustainable energy system can be investigated based on energetic, spatial and environmental indicators. The WWTP under consideration as case study in this work represents an interesting example in this respect.

As indicated in Table 10, concerning the energetic context (internal perspective) the investigated WWTP has a very good energy balance, which can be explained due to a high proportion of co-fermentation. Over the course of the year, both thermal and electrical surpluses are achieved, electrical energy is only drawn from the grid at a few times during the year. The thermal balance is also positive in all months of the year, although only some of the surpluses are used to cover a demand external of the WWTP, some are not used and have to be "destroyed" in emergency cooling. Given that the thermal potential in wastewater that has not yet been utilized in the case study is significantly higher than the chemical potential (in line with Hao et al., 2019), it makes sense to look at the spatial context of the WWTP in order to identify potential energy consumers for the additional renewable energy source of wastewater heat.

To cover the heat demand in the vicinity of the WWTP (spatial context/external perspective), it is necessary to set up a district heating network starting right from the WWTP or to connect it to an existing network. According to this strategic approach presented here, initial rough analyses can be used to prepare the basis for further decisions, whether a grid-bound energy supply could be feasible. The spatial analyses with the representation of the heat demand in the vicinity of the WWTP and the estimation of density parameters (heat demand density, linear heat density) come to the result that a grid-bound energy supply starting from the WWTP can be a feasible option. Thus, sector coupling between wastewater treatment and heat supply appears to be possible in principle (Lichtenwoehrer et al., 2021) and should be considered in further detail.

In regard to the environmental context (external perspective), the use of wastewater energy can contribute to increase the share of renewable energy. Depending on the electricity mix for the additional electricity used to operate the heat pump significant greenhouse gas emissions savings can result. Therefore, WWTPs can make a substantial contribution to reducing greenhouse gas emissions in the heating sector if heating systems based on fossil energy sources are replaced.

With a few indicators, local actors and stakeholders can use the proposed methodology to gain a first impression how a WWTP can be integrated as an energy cell in a local energy system, considering energetic, spatial and environmental aspects. This can be used to identify potentials for sector coupling in the wastewater infrastructure (Schäfer et al., 2020).

\subsection{Strengths and Weaknesses of the Presented Approaches \\ 4.2.1 Estimation of Energy Potentials}

The applied approach provides a quick and good overview on the situation in a specific area of interest only requiring a small set of easily and freely available data. The most promising regions/locations for wastewater-based energy supply can be identified, however, the accuracy of the analysis is limited due to certain assumptions and simplifications. In regard to wastewater heat recovery, this concerns the wastewater flow rate of $1501 / \mathrm{PE}^{\star} \mathrm{d}$, the heat extraction of $5 \mathrm{~K}$, the heat pump COP of 4 , as well as the heat pump operation of $4,500 \mathrm{~h} / \mathrm{a}$. Referring to energy generation from digester gas, this concerns the sole application of mean values (derived from standard ranges) for electric and thermal energy generation $\left(15 \mathrm{kWh}_{\mathrm{el}} /\right.$ $\mathrm{PE}^{\star} \mathrm{a}$ and $30 \mathrm{kWh}_{\mathrm{th}} / \mathrm{PE}^{\star} \mathrm{a}$ ), which are based on Austrian national experiences. With the CORINE Land Cover data used, the spatial context of the WWTPs can be assessed for the entire research area, but in relation to more precise national or regional land-use data there may be limitations in accuracy.

In addition, estimations on the energy potentials are dependent on the input data. The "waterbase" data set is made available in different formats (e. g. csv, shp). Plausibility checks and quality assurance work during data preparation revealed that the different data "sources" are not 100\% identical, neither from a quantitative nor a qualitative perspective. For instance, the amount of WWTPs in the study area, the information in terms of current WWTP capacities and loads as well as the NUTS allocation differ between both datasets. Consequently, missing information in the data source can also have a certain impact on the accuracy of the energy estimation results. Nevertheless, we are convinced that the applied approach provides a useful first impression on the available wastewaterbased energy potentials in an investigated area.

\subsubsection{Integrated Suitability Pre-assessment}

Also the concept to pre-assess a specific WWTP's suitability as local energy cell comprises the benefit of quick information at low data requirements. Based on a small set of rather simple-to-apply criteria, insights in the energetic performance and potential of a WWTP, its specific spatial context, as well as certain environmental boundary conditions are revealed. This provides indications whether a more detailed feasibility study for a specific location (WWTP) appears promising or not.

The evaluation of the energy self-sufficiency applies standard ranges of common activated sludge WWTPs derived under Austrian national framework conditions which neither include the application of co-fermentation nor any type of energy generation apart from digester gas application in CHP units. However, the suggested standard ranges can provide a certain guidance on possible energy optimization measures. Furthermore, more detailed local knowledge about the WWTP external energy demand, as well as the energy mix of the locality, would improve the expressiveness of results. 
The simple analysis of WWTP energy efficiency and the comparison of energy generation potentials at a WWTP and the energy demands in the adjacent infrastructures already provide clear evidence on the basic suitability of a WWTP as a local energy cell. Further investigations only make sense, if surplus energy as well as a certain energy demand in the surroundings already is or can be made available (e. g. due to energy efficiency and generation measures at the WWTP or the development of new energy demanding settlement structures). The suggested environmental aspects are also of a rather general nature, but quickly highlight potential climate benefits related to a possible integration of a specific WWTP into the concerned local energy supply concept.

\section{CONCLUSION AND FUTURE PROSPECTS}

The estimation of the energy potential from wastewater in a spatial context shows great opportunities for the development of additional renewable energy, the integration of which into local energy supply concepts can be supported with a strategic approach grounded in theories and methods of strategic spatial planning and assessment (Stoeglehner, 2020) with the following features: strategic databases that make knowledge readily available and strategic at the beginning of a planning process when stakeholders form their interests and positions (see also Cherp et al., 2007); apply strategic planning and assessment methods that allow for social learning about future options (after Argyris, 1993; Innes and Booher, 2000), mainly deal with questions of demand and general strategic choices (e.g. technology networks) and reduce the information flow on decision makers by supporting strategic choices on the basis of only few indicators in the early stages of planning processes (after Stoeglehner and Narodoslawsky, 2008). The database for energy supply potentials of all 3,315 WWTPs over 5,000 PE in the area under survey (see Supplementary Material) and the proposed method for suitability pre-assessment of WWTPs as local energy cells should support social learning in stakeholder groups so that political decision makers, energy utilities and WWTP operators can jointly discover the potentials of wastewater energy use. Only if these stakeholder groups recognize these potentials, detailed planning processes can be started to pursue energy transition and climate protection by tapping wastewater energy.

The identification of the most promising regions/areas can be understood as a first step to establish WWTPs as local energy cells. The subsequent application of the suitability pre-assessment approach reveals those WWTPs appearing most appropriate for practical implementation. Detailed feasibility studies represent the third and final step of the process which should consider all relevant local framework conditions (e. g. existing energy supply systems, urban development planning) and the renewable electricity supply. Consequently, the involvement of the concerned stakeholders (e. g. wastewater utilities, energy suppliers, municipalities) at an early planning stage is strongly recommended. The joint elaboration of a feasibility study including the definition of intended energy generation and supply scenarios provides the appropriate basis for the development of sustainable and widely accepted solutions (Kretschmer et al., 2018). How to proceed in subsequent feasibility studies has already been well documented in international literature (e.g. Kollmann et al., 2017; Lichtenwoehrer et al., 2021).

To further establish energetic use of wastewater and the application of WWTPs as local energy cells, practical implementations are of crucial importance. Successful applications can serve as demonstration sites and, thus, spur further development. However, apart from technical solutions this also requires an adequate institutional framework, which can support a desired development by regulatory and/or incentive-based as well as stakeholder related measures (Kretschmer, 2017). In this context the REEF 2W eBook (s.a.), 2021 also summarizes various actions to further establish the energetic use of wastewater, differentiating between four different thematic fields - legislation, operation, finance, and cooperation.

The climate crisis is one of the great challenges of our times. The efficient use and the activation of all locally available renewable energy sources are crucial aspects to achieve the energy transition. Wastewater as a renewable source of (thermal) energy could be a valuable component of a future climate friendly energy mix, not only in the EU but in all countries around the world. This article shall help to further establish the energetic use of wastewater and to foster related activities.

\section{DATA AVAILABILITY STATEMENT}

The original contributions presented in the study are included in the article/Supplementary Material, further inquiries can be directed to the corresponding author.

\section{AUTHOR CONTRIBUTIONS}

Conceptualization, GN, FK; Methodology, GN, FK; software, PL, $\mathrm{FH}$; validation, GN, FK, PL, FH, GS; formal analysis, GN, FK; investigation, $\mathrm{PL}, \mathrm{FH}$; data curation, $\mathrm{PL}, \mathrm{FH}$; writing-original draft preparation, GN, FK, PL, FH; writing-review and editing, FK, GS; visualization, PL, GN; supervision, GS; project administration, GN, FK. All authors have read and agreed to the published version of the manuscript.

\section{ACKNOWLEDGMENTS}

The presented research is based on the results of the Interreg Central Europe Project REEF 2W - Increased renewable energy and energy efficiency by integrating, combining and 
empowering urban wastewater and organic waste management systems (REEF $2 \mathrm{~W}$ eBook, s. a.). The article takes up the results of the project and develops them further. The authors are grateful to the project partners for the good and fruitful cooperation.

\section{REFERENCES}

A. R. G. E. Q. M. Fernwärme (Editor) (2021). Planungshandbuch Fernwärme (Planning Manual District Heating). Version 1.3. Ittigen: EnergieSchweiz, Bundesamt für Energie BFE.

Argyris, C. (1993). Knowledge for Action: A Guide to Overcoming Barriers to Organizational Change. 1st ed. San Francisco: Jossey-Bass.

Austria, Statistik. (2021a). Ein Blick auf die Gemeinde Bad Schallerbach Bevölkerungsstand und -struktur 01.01.2021 (A View on the municipality Bad Schallerbach - Population Stock and Structure 01.01.2021). Available at: https://www.statistik.at/blickgem/pr2/g40802.pdf (Accessed September 22, 2021).

Austria, Statistik. (2021b). Ein Blick auf die Gemeinde Wallern an der Trattnach Bevölkerungsstand und -struktur 01.01.2021 (A View on the municipality Wallern an der Trattnach - Population Stock and Structure 01.01.2021). Available at: https://www.statistik.at/blickgem/pr2/g40832.pdf (Accessed September 22, 2021).

AWEL (2010), Heizen und Kühlen mit Abwasser - Leitfaden für die Planung, Bewilligung und Realisierung von Anlagen zur Abwasserenergienutzung (Heating and Cooling with Wastewater - Guideline for Planning, Approving and Realising Energetic Use of Wastewater). Zürich: Amt für Abfall, Wasser, Energie und Luft (AWEL).

Cecconet, D., Raček, J., Callegari, A., and Hlavínek, P. (2019). Energy Recovery from Wastewater: A Study on Heating and Cooling of a Multipurpose Building with Sewage-Reclaimed Heat Energy. Sustainability 12, 116. doi:10.3390/ su12010116

Cherp, A., Watt, A., and Vinichenko, V. (2007). SEA and Strategy Formation Theories: From Three Ps to Five Ps. Environ. Impact Assess. Rev. 27, 624-644. doi:10.1016/j.eiar.2007.05.008

Culha, O., Gunerhan, H., Biyik, E., Ekren, O., and Hepbasli, A. (2015). Heat Exchanger Applications in Wastewater Source Heat Pumps for Buildings: A Key Review. Energy and Buildings 104, 215-232. doi:10.1016/ j.enbuild.2015.07.013

Directive (EU) (2018). Directive (EU) 2018/2001 of the European Parliament and of the Council of 11 December 2018 on the Promotion of the Use of Energy from Renewable Sources (Recast).

Dochev, I., Peters, I., Seller, H., and Schuchardt, G. K. (2018). Analysing District Heating Potential with Linear Heat Density. A Case Study from Hamburg. Energ. Proced. 149, 410-419. doi:10.1016/ j.egypro.2018.08.205

DWA-M114 (2020). Abwasserwärmenutzung (Wastewater Heat Recovery). Hennef, Deutschland: German Water Association (DWA).

EC (2016). Communication from the Commission to the European Parliament, the Council, the European Economic and Social Committee and the Committee of the Regions. An EU Strategy on Heating and Cooling. COM(2016) 51 Final. Available at: https://ec.europa.eu/energy/sites/ener/files/documents/1_EN_ ACT_part1_v14.pdf (Accessed September 21, 2021).

EC (2019). Communication from the Commission to the European Parliament, the European Council, the Council, the European Economic and Social Committee and the Committee of the Regions. The European Grean Deal. COM(2019) 640 Final. Available at: https://ec.europa.eu/info/sites/default/files/european-greendeal-communication_en.pdf (Accessed September 21, 2021).

EEA (2021). Corine Land Cover (CLC) 2018, Version 2020_20_u1. Available at: https://land.copernicus.eu/pan-european/corine-land-cover/clc2018? tab $=$ download (Accessed May 22, 2021).

EEA (2019). Waterbase - UWWTD: Urban Waste Water Treatment Directive Reported Data. Available at: https://www.eea.europa.eu/data-and-maps/data/ waterbase-uwwtd-urban-waste-water-treatment-directive-7 (Accessed May 22, 2021).

\section{SUPPLEMENTARY MATERIAL}

The Supplementary Material for this article can be found online at: https://www.frontiersin.org/articles/10.3389/fenvs.2021.785557/ full\#supplementary-material

Elías-Maxil, J. A., van der Hoek, J. P., Hofman, J., and Rietveld, L. (2014). Energy in the Urban Water Cycle: Actions to Reduce the Total Expenditure of Fossil Fuels with Emphasis on Heat Reclamation from Urban Water. Renew. Sust. Energ. Rev. 30, 808-820. doi:10.1016/j.rser.2013.10.007

European CommissionEurostat (ESTAT)GISCO (2018). Administrative Units/ Statistical Units. Nomenclature of Territorial Units for Statistics (NUTS) 2016 - Statistical Units - Data Set. Available at: https://ec.europa.eu/ eurostat/de/web/gisco/geodata/reference-data/administrative-units-statisticalunits (Accessed April 15, 2021).

Frijns, J., Hofman, J., and Nederlof, M. (2013). The Potential of (Waste)water as Energy Carrier. Energ. Convers. Manag. 65, 357-363. doi:10.1016/ j.enconman.2012.08.023

Gruber-Glatzl, W., Brunner, C., Meitz, S., and Schnitzer, H. (2020). From the Wastewater Treatment Plant to the Turnstiles of Urban Water and District Heating Networks. Front. Sustain. Cities 2, 523698. doi:10.3389/ frsc.2020.523698

Hao, X., Li, J., van Loosdrecht, M. C. M., Jiang, H., and Liu, R. (2019). Energy Recovery from Wastewater: Heat over Organics. Water Res. 161, 74-77. doi:10.1016/j.watres.2019.05.106

Huber, F., Neugebauer, G., Ertl, T., and Kretschmer, F. (2020). Suitability Preassessment of In-Sewer Heat Recovery Sites Combining Energy and Wastewater Perspectives. Energies 13, 6680. doi:10.3390/en13246680

Innes, J. E., and Booher, D. E. (2000). Collaborative Dialogue as a Policy Making Strategy. Berkeley: Institute of Urban \& Regional Development. Available at: http://escholarship.org/uc/item/8523r5zt (Accessed October 24, 2016).

Jalil-Vega, F., and Hawkes, A. D. (2018). Spatially Resolved Model for Studying Decarbonisation Pathways for Heat Supply and Infrastructure Trade-Offs. Appl. Energ. 210, 1051-1072. doi:10.1016/j.apenergy.2017.05.091

Koffi, B., Cerutti, A. K., Duerr, M., Iancu, A., Janssens-Maenhout, G., Kona, A., et al. (2017). Covenant of Mayors for Climate and Energy: Default Emission Factors for Local Emission Inventories : Version 2017. Available at: http://dx.publications.europa.eu/10.2760/290197 (Accessed September 28, 2021).

Kollmann, R., Neugebauer, G., Kretschmer, F., Truger, B., Kindermann, H., Stoeglehner, G., et al. (2017). Renewable Energy from Wastewater Practical Aspects of Integrating a Wastewater Treatment Plant into Local Energy Supply Concepts. J. Clean. Prod. 155 (Part 1), 119-129. doi:10.1016/ j.jclepro.2016.08.168

Kordana, S., Pochwat, K., Słyś, D., and Starzec, M. (2019). Opportunities and Threats of Implementing Drain Water Heat Recovery Units in Poland. Resources 8, 88. doi:10.3390/resources8020088

Kranzl, S. (2018). Treibhausgasemissionen von Strom. Empfehlungen zur ÖkoBilanzierung (Greenhouse gas emissions from electricity. Vienna: Umweltbundesamt Wien. Recommendations for eco-balancing).

Kretschmer, F. (2017). "Abwasser als erneuerbare Energiequelle - Potenziale, Chancen und Barrieren im österreichischen Kontext (Wastewater as a Renewable Energy Source - Potentials, Chances and Barriers in the Austrian Context)," in Wiener Mitteilungen 246, 101

Kretschmer, F., Hrdy, B., Neugebauer, G., and Stoeglehner, G. (2021). Wastewater Treatment Plants as Local Thermal Power Stations-Modifying Internal Heat Supply for Covering External Heat Demand. Processes 9, 1981. doi:10.3390/ pr9111981

Kretschmer, F., Neugebauer, G., Stoeglehner, G., and Ertl, T. (2018). Participation as a Key Aspect for Establishing Wastewater as a Source of Renewable Energy. Energies 11, 3232. doi:10.3390/en11113232

Lichtenwoehrer, P., Abart-Heriszt, L., Kretschmer, F., Suppan, F., Stoeglehner, G., and Neugebauer, G. (2021). Evaluating Spatial Interdependencies of Sector Coupling Using Spatiotemporal Modelling. Energies 14, 1256. doi:10.3390/ en14051256 
Lindtner, S. (2008). Leitfaden zur Erstellung eines Energiekonzeptes Kommunaler Kläranlagen (Guideline for the Development of an Energy Concept for Municipal Wastewater Treatment Plants). Vienna: Austrian Federal Ministry of Agriculture, Forestry, Environment and Water Management (BMLFUW.

Llácer-Iglesias, R. M., López-Jiménez, P. A., and Pérez-Sánchez, M. (2021). Energy Self-Sufficiency Aiming for Sustainable Wastewater Systems: Are All Options Being Explored? Sustainability 13, 5537. doi:10.3390/su13105537

Mo, W., and Zhang, Q. (2013). Energy-nutrients-water Nexus: Integrated Resource Recovery in Municipal Wastewater Treatment Plants. J. Environ. Manage. 127, 255-267. doi:10.1016/j.jenvman.2013.05.007

Munoz-Cupa, C., Hu, Y., Xu, C., and Bassi, A. (2021). An Overview of Microbial Fuel Cell Usage in Wastewater Treatment, Resource Recovery and Energy Production. Sci. Total Environ. 754, 142429. doi:10.1016/ j.scitotenv.2020.142429

Neugebauer, G., Kretschmer, F., Kollmann, R., Narodoslawsky, M., Ertl, T., and Stoeglehner, G. (2015). Mapping Thermal Energy Resource Potentials from Wastewater Treatment Plants. Sustainability 7, 12988-13010. doi:10.3390/ su71012988

Nielsen, S., Hansen, K., Lund, R., and Moreno, D. (2020). Unconventional Excess Heat Sources for District Heating in a National Energy System Context. Energies 13, 5068. doi:10.3390/en13195068

Nowak, O., Enderle, P., and Varbanov, P. (2015). Ways to Optimize the Energy Balance of Municipal Wastewater Systems: Lessons Learned from Austrian Applications. J. Clean. Prod. 88, 125-131. doi:10.1016/j.jclepro.2014.08.068

ÖWAV-AB 65 (2021). Energetische Nutzung des thermischen Potenzials von Abwasser (Energetic Use of the Thermal Potential of Wastewater). Vienna: Austrian Water and Waste Association (ÖWAV.

Piotrowska, B., Słýs, D., Kordana-Obuch, S., and Pochwat, K. (2020). Critical Analysis of the Current State of Knowledge in the Field of Waste Heat Recovery in Sewage Systems. Resources 9, 72. doi:10.3390/resources9060072

Pochwat, K., Kordana-Obuch, S., Starzec, M., and Piotrowska, B. (2020). Financial Analysis of the Use of Two Horizontal Drain Water Heat Recovery Units. Energies 13, 4113. doi:10.3390/en13164113

REEF 2 W eBook (s.a.) (2021). REEF 2W - Increased Renewable Energy and Energy Efficiency by Integrating, Combining and Empowering Urban Wastewater and Organic Waste Management Systems. Available at: https://www.interregcentral.eu/Content.Node/Reef2W-eBook-final.pdf (Accessed June 24, 2021).

RHV (s.a.) (2021). Abwasserverband Trattnachtal - Anlage und Leistungen (Wastewater Utility Trattnachtal - Description of the WWTP. Available at: https://www.rhv-trattnachtal.at/anlage-leistungen (Accessed February 11, 2021).

Schäfer, M., Gretzschel, O., and Steinmetz, H. (2020). The Possible Roles of Wastewater Treatment Plants in Sector Coupling. Energies 13, 2088. doi:10.3390/en 13082088

Schopf, K., Judex, J., Schmid, B., and Kienberger, T. (2018). Modelling the Bioenergy Potential of Municipal Wastewater Treatment Plants. Water Sci. Techn. 77, 2623-2613. doi:10.2166/wst.2018.222
Spriet, J., and McNabola, A. (2019). Decentralized drain Water Heat Recovery from Commercial Kitchens in the Hospitality Sector. Energy and Buildings 194, 247-259. doi:10.1016/j.enbuild.2019.04.032

Spriet, J., McNabola, A., Neugebauer, G., Stoeglehner, G., Ertl, T., and Kretschmer, F. (2020). Spatial and Temporal Considerations in the Performance of Wastewater Heat Recovery Systems. J. Clean. Prod. 247, 119583. doi:10.1016/j.jclepro.2019.119583

Stoeglehner, G., and Narodoslawsky, M. (2008). Implementing Ecological Footprinting in Decision-Making Processes. Land Use Policy 25, 421-431. doi:10.1016/j.landusepol.2007.10.002

Stoeglehner, G., Neugebauer, G., Erker, S., and Narodoslawsky, M. (2016). Integrated Spatial and Energy Planning. Cham: Springer International Publishing. Available at: http://link.springer.com/10.1007/978-3-319-31870-7 (Accessed November 4, 2016).

Stoeglehner, G. (2020). Strategicness - the Core Issue of Environmental Planning and Assessment of the 21st century. Impact Assess. Project Appraisal 38, 141-145. doi:10.1080/14615517.2019.1678969

UBA (2019). Berechnung von Treibhausgas (THG)-Emissionen verschiedener Energieträger (Calculation of greenhouse gas (GHG) emissions from different energy sources). Available at: https://secure.umweltbundesamt.at/ co2mon/co2mon.html (Accessed September 24, 2021).

Yang, X., Wei, J., Ye, G., Zhao, Y., Li, Z., Qiu, G., et al. (2020). The Correlations Among Wastewater Internal Energy, Energy Consumption and Energy Recovery/production Potentials in Wastewater Treatment Plant: An Assessment of the Energy Balance. Sci. Total Environ. 714, 136655. doi:10.1016/j.scitotenv.2020.136655

Zach, F., Lichtenwoehrer, P., Neugebauer, G., and Kretschmer, F. (2019). REEF 2W Machbarkeitsstudie - Fallbeispiel RHV Trattnachtal (REEF 2W Case Study Wastewater Utility Trattnachtal). Wiener Mitteilungen 51, K1-K11.

Conflict of Interest: The authors declare that the research was conducted in the absence of any commercial or financial relationships that could be construed as a potential conflict of interest.

Publisher's Note: All claims expressed in this article are solely those of the authors and do not necessarily represent those of their affiliated organizations, or those of the publisher, the editors and the reviewers. Any product that may be evaluated in this article, or claim that may be made by its manufacturer, is not guaranteed or endorsed by the publisher.

Copyright (๑) 2022 Neugebauer, Lichtenwoehrer, Huber, Stoeglehner and Kretschmer. This is an open-access article distributed under the terms of the Creative Commons Attribution License (CC BY). The use, distribution or reproduction in other forums is permitted, provided the original author(s) and the copyright owner(s) are credited and that the original publication in this journal is cited, in accordance with accepted academic practice. No use, distribution or reproduction is permitted which does not comply with these terms. 